\title{
CURRENT DATA CONCERNING INCIDENCE AND PREVALENCE OF DIABETES MELLITUS IN BIHOR COUNTY
}

\author{
Vesa Cosmin Mihai ${ }^{1,2}$, Daina Lucia Georgeta ${ }^{1,2}$, Popa Loredana ${ }^{1}$, Moisi Mădălina ${ }^{1,2}$, \\ Zaha Carmen Dana ${ }^{1,2}$, Popa Amorin Remus ${ }^{1,2}$ \\ ${ }^{1}$ Clinical County Emergency Hospital of Oradea,v_cosmin_15@yahoo.com \\ ${ }^{2}$ Faculty of Medicine and Pharmacy from Oradea, University of Oradea
}

\begin{abstract}
Diabetes incidence in Bihor County in 2016 was $0.55 \%$ or $558 / 100.000$ and in 2017 was $0.43 \%$ or $437 / 100.000$. The prevalence of diabetes was $5.24 \%$ in 2016 and $5.48 \%$ in 2017. Age adjusted prevalence was $7.20 \%$ in 2016 and $7.66 \%$ in 2017 , in the $20-79$ age group. This prevalence is lower than the national prevalence from PREDATORR study of 11.6\%. Data from diabetes registers underestimate diabetes prevalence. As a consequence it is mandatory to effectuate a screening of diabetes mellitus in Bihor County.
\end{abstract}

Key words: diabetes mellitus epidemiology

\section{Rezumat}

Incidența diabetului zaharat în județul Bihor în anul 2016 a fost de 0,55\% sau 558 de cazuri noi la 100.000 de persoane, iar în anul 2017 a fost de 0,43\% sau 437 de cazuri noi la 100.000 de persoane. Prevalența diabetului zaharat a fost de 5,24\% în 2016 și de 5,48\% în anul 2017. Prevalența ajustată în funcție de vârstă a fost de 7,20\% în anul 2016 și de 7,66\% în anul 2017, la grupa de vârstă între 20-79 de ani. Această prevalență este mai mică decât prevalența națională din studiul PREDATORR de 11,6\%. Datele din registrele de diabet subestimează prevalența diabetului zaharat. Ca o consecință este obligatorie efectuarea unui screening al diabetului zaharat în județul Bihor.

Cuvinte cheie: epidemiologia diabetului zaharat. 


\section{INTERNAL}

\section{Original papers}

\section{Introduction}

The prevalence of diabetes mellitus is growing worldwide; International Diabetes Federation states that there are 424 million cases worldwide. The cost for healthcare related to diabetes was 727 billion dollars in 2017. The prevalence of diabetes in the age group $20-79$ is approximately $8.8 \%{ }^{(1)}$.

In this paper we have the goal to determine the demographic indicators of diabetes mellitus in Bihor County and to compare it with data provided by other studies effectuated in Romania.

\section{Material and methods}

In this paper firstly there is presented data from literature concerning the prevalence of type 1 and type 2 diabetes worldwide and in Romania, then determination of incidence and prevalence is made for Bihor County. After that we do a comparative analysis of the local data to the national data concerning diabetes epidemiology.

Data concerning diabetes mellitus was collected from the Diabetes Centre Bihor, where all the newly diagnosed patients are registered. In the moment of registration a record file concerning the disease is made for every patient, concerning their age, sex, year of diagnosis, glycaemic parameters, high blood pressure, dyslipidaemia and other comorbidities, recommended treatment. The file is updated at every new evaluation or when changes of treatment are made.

\section{Results and discussions}

\section{Type 1 diabetes epidemiology}

Worldwide there are approximatively 20 million cases of type 1 diabetes. The incidence of type 1 diabetes is growing with approximately $3 \%$ a year ${ }^{(2)}$. In Europe type 1 diabetes had a growing of $3.9 \%$ a year, the biggest growth of $5.4 \%$ being registered in the $0-5$ age group, followed by a growth of $4.3 \%$ in the 5-9 age group, the lowest growth of $2.9 \%$ being registered in the $10-14$ age group.

Every year are diagnosed approximately 132.000 children and adolescents with age lower than 20 and there are approximatively 1.100 .000 persons living with type 1 diabetes in the age group lower than $20^{(1)}$. Type 1 diabetes is characterized by an incidence that varies significantly by the geographic region, in Finland there are approximatively 60/100.000/year while in China there are $0.1 / 100.000 /$ year $^{(3)}$. In Romania the incidence of type 1 diabetes in 2015 was 11/100.000/year higher than in 1996 when the incidence was 4.7/ 100.000/ year, the growth being of approximately $5.1 \%$ a year ${ }^{(4)}$. 


\begin{tabular}{|c|c|c|c|c|}
\hline Year & $\begin{array}{c}\text { Number of newly } \\
\text { diagnosed cases }\end{array}$ & $\begin{array}{c}\text { Incidence/ } \\
100 \text { persons }\end{array}$ & $\begin{array}{c}\text { Incidence/ } \\
1000 \text { persons }\end{array}$ & $\begin{array}{c}\text { Incidence/ } \\
100000 \text { persons }\end{array}$ \\
\hline 2007 & 2825 & $0.4751 \%$ & 4.75 & 475 \\
\hline 2008 & 4474 & $0.7550 \%$ & 7.55 & 755 \\
\hline 2009 & 2586 & $0.4363 \%$ & 4.36 & 436 \\
\hline 2010 & 2483 & $0.4197 \%$ & 4.20 & 419 \\
\hline 2011 & 2069 & $0.3496 \%$ & 3.50 & 414 \\
\hline 2012 & 2453 & $0.4143 \%$ & 4.14 & 393 \\
\hline 2013 & 2326 & $0.3939 \%$ & 3.94 & 421 \\
\hline 2014 & 2489 & $0.4218 \%$ & 4.22 & 426 \\
\hline 2015 & 2642 & $0.4265 \%$ & 4.27 & 558 \\
\hline 2016 & 3451 & $0.5580 \%$ & 5.58 & 437 \\
\hline 2017 & 2705 & $0.4378 \%$ & 4.38 & \\
\hline
\end{tabular}

Table 1. Incidence of diabetes in Bihor county 2007 to 2017

\begin{tabular}{|c|c|}
\hline Year & Prevalence \\
\hline 2007 & $3.65 \%$ \\
\hline 2008 & $4.02 \%$ \\
\hline 2009 & $4.07 \%$ \\
\hline 2010 & $4.42 \%$ \\
\hline 2011 & $4.71 \%$ \\
\hline 2012 & $5.02 \%$ \\
\hline 2013 & $4.79 \%$ \\
\hline 2014 & $5.07 \%$ \\
\hline 2015 & $5.17 \%$ \\
\hline 2016 & $5.24 \%$ \\
\hline 2017 & $5.48 \%$ \\
\hline & \\
\hline
\end{tabular}


Original papers

\section{Type 2 diabetes epidemiology}

In developed countries it is estimated that $87 \%$ to $91 \%$ of diabetes cases are type 2 diabetes cases $^{(1)}$. Type 2 diabetes had a prevalence of $11 \%$ in North America, $10.8 \%$ in Middle East, $6.8 \%$ in Europe, 4.4\% in Africa. In 2017 it is estimated that 4 million people died in the 20 79 age group of diabetes complications, which represent $10 \%$ of mortality causes in this population $^{(1)}$. The prevalence of diabetes has the fastest growth in developing countries. The prevalence of type 2 diabetes increased 10 times in India from $1.2 \%$ in 1971 to $12.1 \%$ in $2000^{(5)}$. However in developed countries diabetes prevalence continues to grow, in United States of America the prevalence grew from $9.8 \%$ in $1988-1994$ to $12.4 \%$ in 2011 $2012^{(11)}$.

In Romania in 2011 diabetes prevalence was $4.21 \%$ based on the data from diabetes registries ${ }^{(6)}$. Diabetes was more frequent in women, $52.43 \%$ vs. men $47.57 \%{ }^{(6)}$. The incidence of diabetes in 2011 in Romania was 358.3/100.000. PREDATORR study done between 2013 to 2014 demonstrated that the prevalence of diabetes mellitus in Romania was $11.6 \%{ }^{(7)}$. The discrepancy can be explained by the design of PREDATORR study, the prevalence is determined in a representative sample from the Romanian population. Also the prevalence is determined in the 20-79 age group. In the PREDATORR study the prevalence of diabetes was more increased in men, $13 \%$, than in women, $9.3 \%$. The prevalence in the $60-79$ age group was $21.9 \%$. In the $20-39$ age group the prevalence was $3 \%$ and in the 40-59 age group the prevalence was $13.4 \%$. The prevalence of hypertension in diabetes patients was $87.8 \%$.

\section{Diabetes incidence and prevalence in Bihor County}

Diabetes incidence in Bihor County in 2016 was $0.55 \%$ or $558 / 100.000$ and in 2017 was $0.43 \%$ or $437 / 100.000$. In the $2007-2017$ period the average incidence was $0.46 \%$. The highest incidence was in 2008 of $0.75 \%$. The most probable explication of this high prevalence in 2008 is the development of the National Program for the Evaluation of Population Health during the period of 1 July 2017 to 31 December 2008. Analysing the incidence of diabetes in Bihor County we observe that in no other year after 2008 the incidence wasn't higher than $0.75 \%$.

Early diagnosis of diabetes reduces the risk of cardiovascular complica-tions, it was demonstrated that a diagnosis with 6 years earlier reduces the absolute risk of cardiovascular disease with $4.9 \%$ and the relative risk with $29 \%{ }^{(8)}$. In a representative sample of newly diagnosed diabetes patients from Bihor County the risk of coronary artery disease morbidity at 10 years was $18.10 \%$ in 


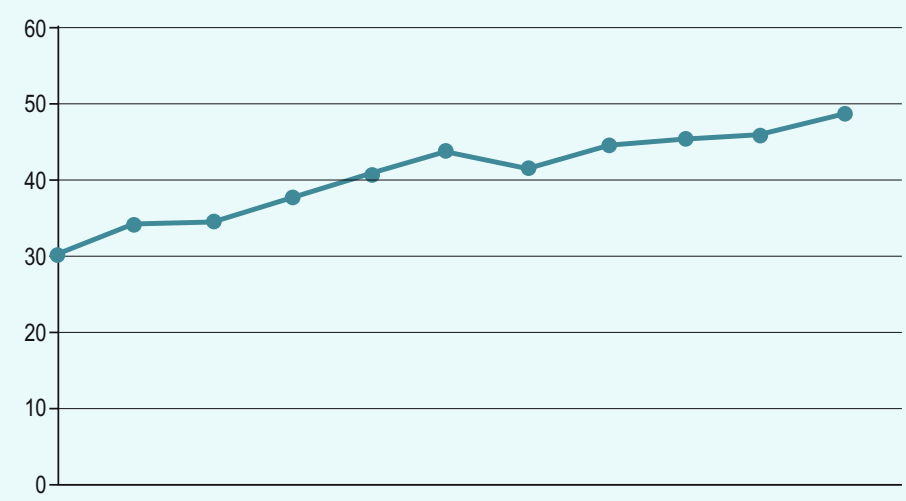

Figure 1. Prevalence of diabetes mellitus in Bihor County

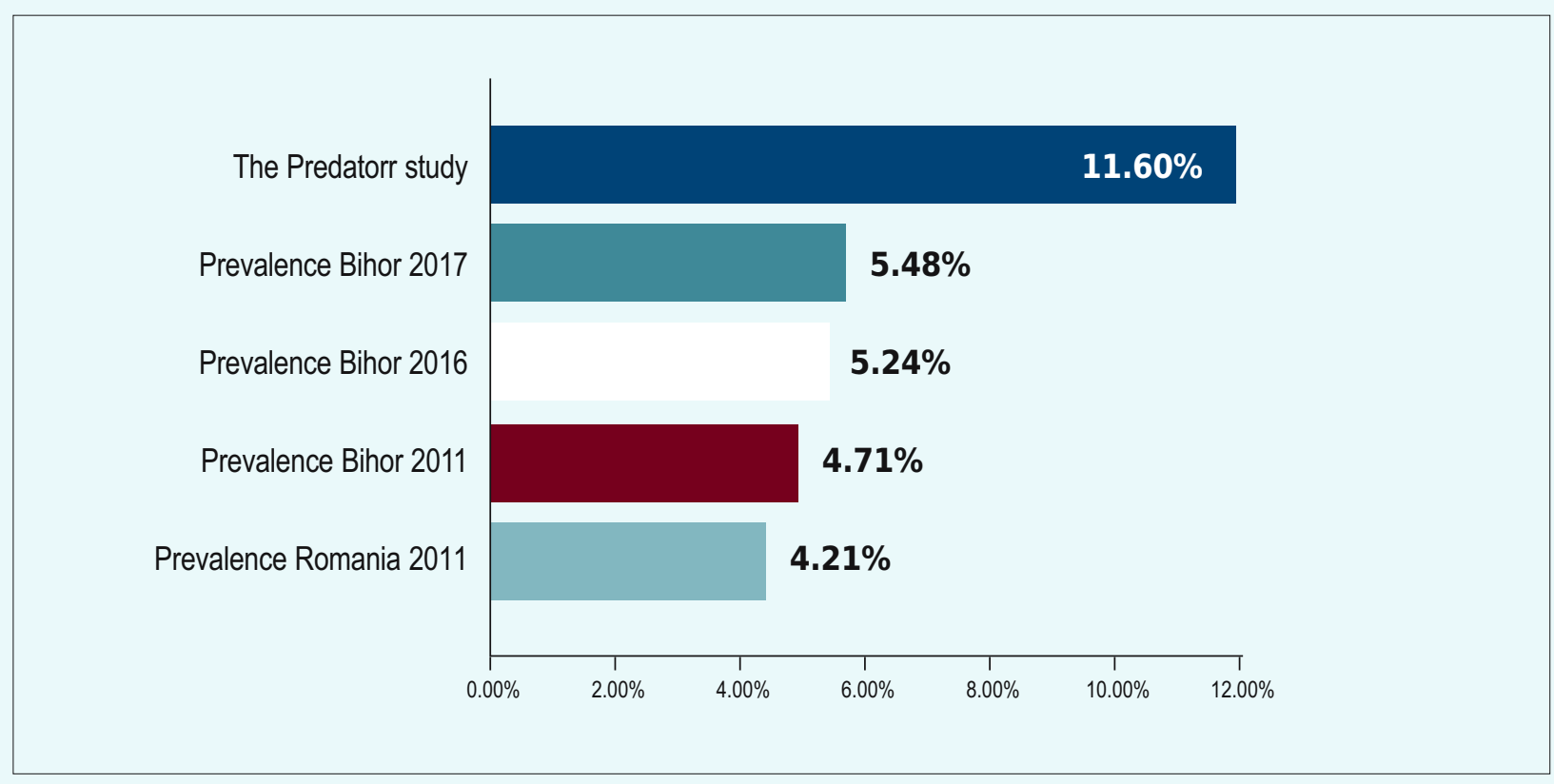

Figure 2. Comparison of diabetes prevalence in Bihor County in 2016, in 2017, in Romania 2011 and in PREDATORR study

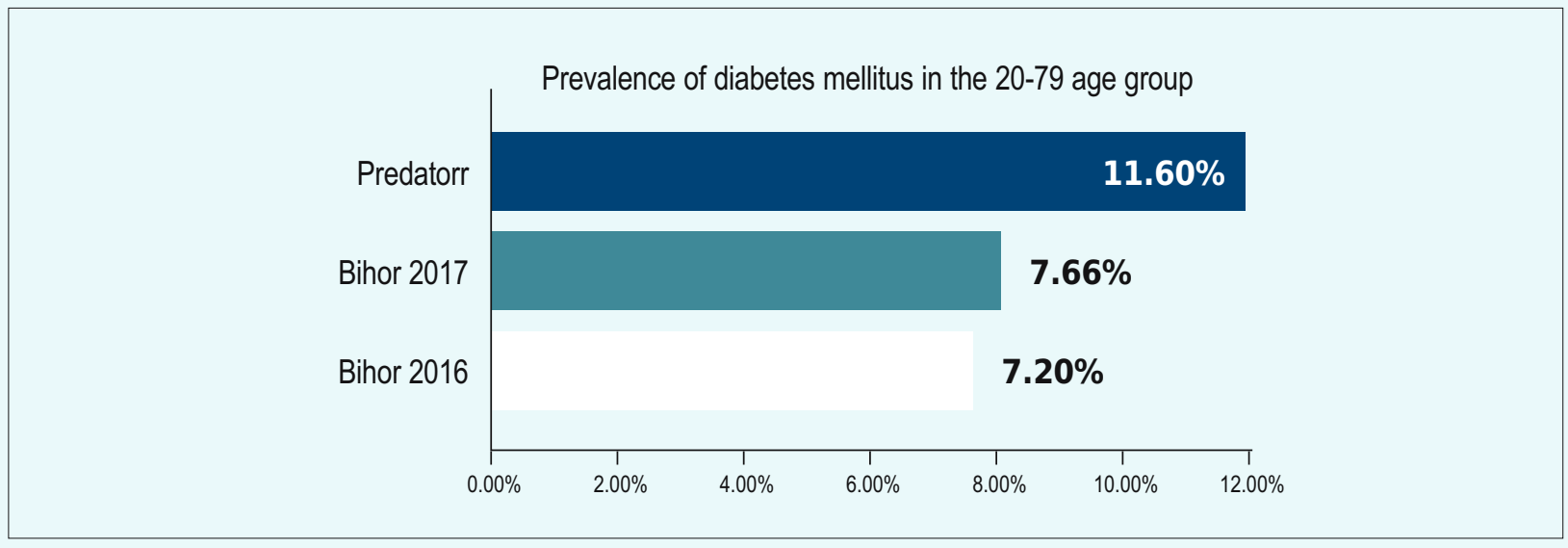

Figure 3. Comparison of diabetes mellitus in the age group 20-79 in Bihor county in 2016 and 2017 and in PREDATORR study 


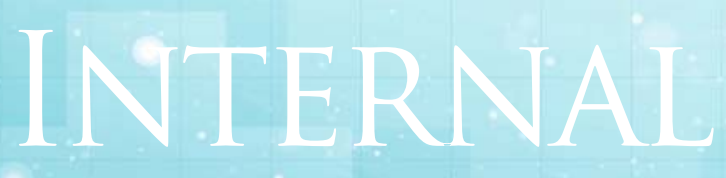

Original papers

men and $10.70 \%$ in women ${ }^{(9)}$. Studies demonstrated that the screening of diabetes is cost-efficient $^{(10)}$.

American Diabetes Association recommends screening of diabetes mellitus in patients with risk factors. In obese and overweight patients screening is recommen-ded at any age, an in the other persons the screening is recommend after 45 years $^{(12)}$. These results suggest the need of screening programs for diabetes mellitus both in our county and at the national level for early diagnosis and reducing the costs for complications treatment. Diabetes type 1 had a low incidence in Bihor County of 2.99/100.000 in 2016 and 3.88/100.000 in 2017 much lower than the national incidence.

Diabetes mellitus prevalence in Bihor County in 2016 was $5.24 \%$ and in 2017 was $4.48 \%$. In Bihor County diabetes prevalence had an ascending rend in the past 10 years. If we compare the prevalence of diabetes in 2017 , of $3.65 \%$, with the prevalence in 2017, we observe that in Bihor County the prevalence of diabetes increased with $150 \%$ in 10 years. The prevalence in 2016 and 2016 is not adjusted according to age.

\section{Comparison of diabetes epidemiology in Bihor County with the national epidemiology}

In order to compare the local prevalence with the national prevalence $\mathrm{i}$ selected two studies one performed in 2011 and PREDATORR study performed between 20132014. In 2011 the national prevalence of diabetes was 4.21\%. In Bihor County in 2011 the prevalence of diabetes was $4.71 \%$ greater than the national average. The PREDATORR study demonstrated a prevalence of $11.6 \%(95 \% \mathrm{Cl} 9.6 \%-13.6 \%)$ in Romania of which $2.44 \%(95 \% \mathrm{Cl} 1.7 \%-3.1 \%)$ represent newly diagnosed cases. The difference between the prevalence of diabetes as cited by PREDATORR study and the prevalence of diabetes in Bihor County in 2017 is at first sight significant. However at a close look we notice that in PREDATORR study the prevalence of diabetes was determined in a representative sample for the country's population.

In this sample there were done biochemical tests and oral glucose tolerance test was performed. So the population was screened for the presence of diabetes and from the $11.6 \%$ prevalence $2.4 \%$ are newly diagnosed cases. Also in PREDATORR study the prevalence was determined in the 20-79 age group. After adjustment according to age the prevalence of diabetes in Bihor County in the age group $20-79$ years was $7.20 \%$ in 2016 and $7.66 \%$ in 2017. These results lead to the conclusion that data from the registries underestimate the diabetes prevalence and that there is a need for the screening of diabetes mellitus in Bihor County. 


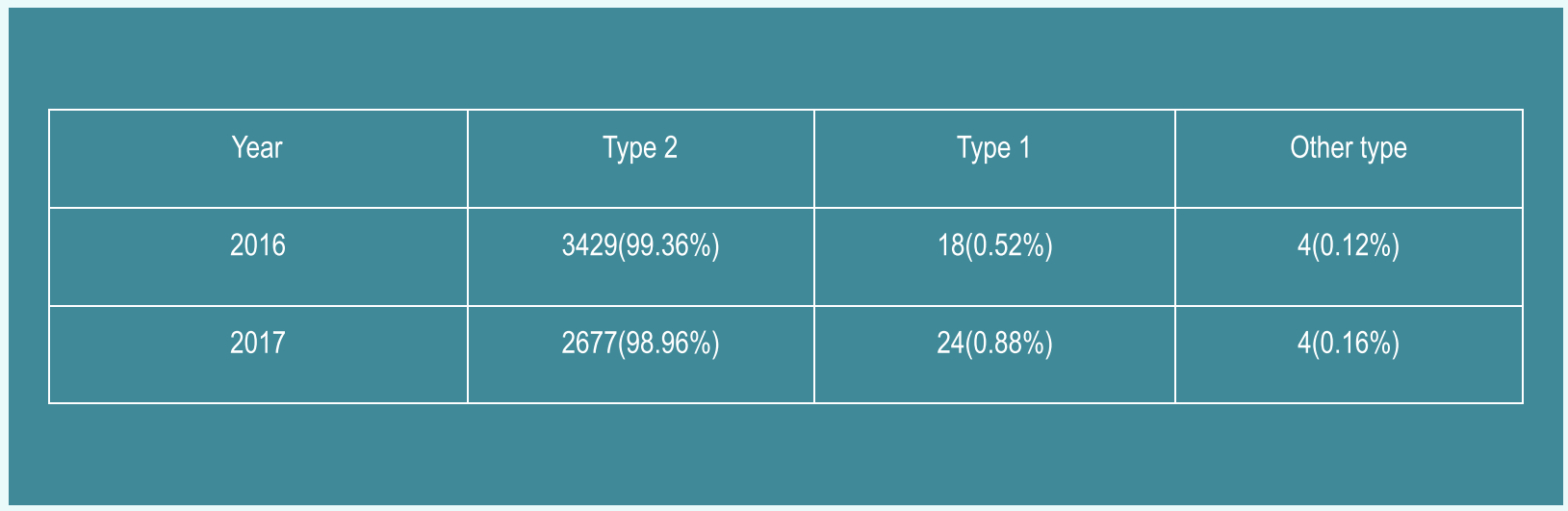

Table 3. Distribution of diabetes cases according to type in Bihor county

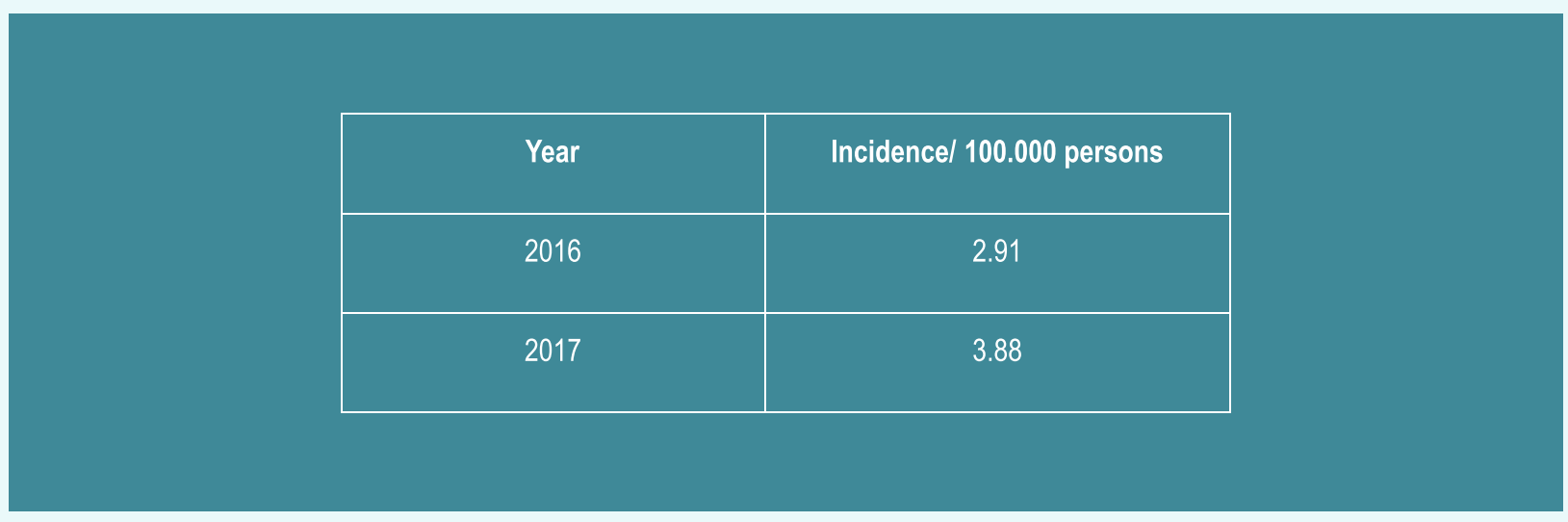

Table 4. Incidence of type 1 diabetes in Bihor County

\section{Conclusions}

Diabetes mellitus prevalence in Bihor County was $5.24 \%$ in 2016 and $5.48 \%$ in 2017 . The prevalence of diabetes increased with $150 \%$ from 2007 to 2017. Diabetes type 2 represent most cases of diabetes in Bihor County, type 1 diabetes has a very low incidence. Data from the registries underestimate diabetes prevalence of diabetes, there is a need to realize a screening of diabetes mellitus in Bihor County.

\section{References}

1. IDF DIABETES ATLAS, Eighth edition 2017

2. Onkamo P1, Väänänen S, Karvonen M, TuomilehtoJ., Worldwide increase in incidence of Type I diabetes--the analysis of the data on published incidence trends., Diabetologia. 1999 Dec;42(12):1395-403.
3. Patterson CC, Dahlquist GG, Gyürüs $E$, Green $A$, Soltész G, EURODIAB Study Group, Incidence trends for childhood type 1 diabetes in Europe during 1989-2003 and predicted new cases 2005-20: a multicentre prospective registration study., Lancet. 2009 Jun 13; 373(9680):2027-33.

4. Adrian Vlad, Viorel Serban, et.al., Time trends, regional variability and seasonality regarding the incidence of type 1 diabetes mellitus in Romanian children aged 0-14 years, between 1996 and 2015, Clin Res Pediatr Endocrinol. 2017.

5. Ramachandran A, Snehalatha C. Current scenario of diabetes in India. J Diabetes. 2009;1(1):18-28

6. Moța M, Dinu I.R, The Analysis Of Prevalence And Incidence of Diabetes Mellitus In Romania, Rom J Diabetes Nutr Metab Dis. 20(2):135-139

7. Mota M, Popa SG, Mota E, Mitrea A, Prevalence of diabetes mellitus and prediabetes in the adult Romanian population: PREDATORR study, J Diabetes. 2016 May;8(3):336-44

8. William H. Herman, Wen Ye, Early Detection and Treatment of Type 2 Diabetes Reduce Cardiovascular Morbidity and Mortality: A Simulation of the Results of the Anglo-Danish-Dutch Study of Intensive Treatment in 


\section{Original papers}

People With Screen-Detected Diabetes in Primary Care (ADDITION-Europe), Diabetes Care 2015 Aug; 38(8): 1449-1455

9. Vesa Cosmin Mihai, Zaha Carmen Dana, Popa Loredana, Cismaș-Pruteanu Petrișor, Moisi Mădălina, Popescu Mircea, Florica Mekereș, Daina Lucia, Maghiar Adrian, Popa Amorin, Cross - Sectional Study on a Population of Diabetes Mellitus Newly Diagnosed Patients. Relative Risk of Coronary Heart Disease (CHD) Morbidity Using UKPDS Risk Engine, Internal Medicine,
Volume 15, Issue 1, Pages 7-15, ISSN (Online) 1220-581 10. Behzad Najafi, Farshad Farzadfar, Cost effectiveness of type 2 diabetes screening: $A$ systematic review, Med J Islam Repub Iran. 2016; 30: 326.

11. Andy Menke, Prevalence of and Trends in Diabetes Among Adults in the United States, 1988-2012, JAMA. 2015;314(10):1021-1029

12. American Diabetes Association Standards of Medical Care In Diabetes - 2017 